\title{
Reframing performance management praxis at the Harare city council
}

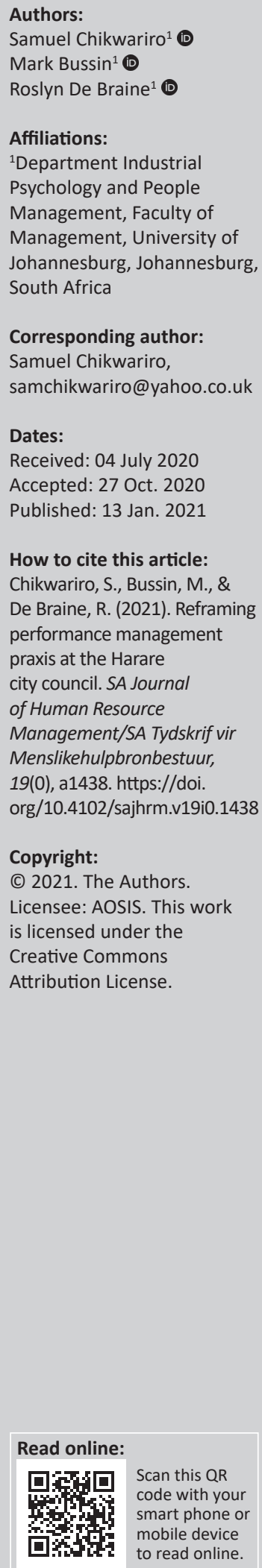

Orientation: The study is a response from the complaints arising from the performance deficiencies of Harare City Council (HCC) employees. This brought into focus the need to reframe the performance management (PM) practises to match or exceed the stakeholder expectations.

Research purpose: The study sought to understand factors that could improve employee performance at HCC in line with the requirements of the performance tool.

Motivation for the study: The study's findings may assist the management at HCC to improve manpower utilisation towards the achievement of the city's service delivery objectives.

Research approach/design and method: This is a qualitative study that used the interpretivist approach to understand the lived experiences and perceptions of employees towards the PM. Purposive sampling was used to identify 10 participants who were interviewed following a semi-structured questionnaire.

Main findings: The study revealed that the implementation of PM is facing hindrances because of factors in both the internal and external environment. Therefore, collective effort is required to overcome the challenges and improve implementation of the PM at HCC.

Practical implications: Line managers should explore available reward options to enhance employee motivation, adopt an inclusive approach in addressing the institutionally created barriers to the PM and further attend to other challenges inhibiting employee performance.

Contribution/value-add: The discovery of the inadequacies of the PM at HCC provided a new insight of perceptions towards PM at HCC. Therefore, the study was able to recommend practices that support the improvement of the PM implementation.

Keywords: employee motivation; inclusion; learning transfer; institutional factors; organisational effectiveness.

\section{Introduction}

\section{Orientation}

Like other resources, employees must be managed to perform as expected (Mwangi \& Njuguna, 2019). The achievement of organisational goals does not depend on the mere availability of resources, but on how they are managed to produce desired results (Aguinis, 2019; Armstrong, 2014). The management of employee performance has a central role in ensuring the achievement of organisational goals (Hamid, Muzamil, \& Shah, 2019; Kossivi, Xu, \& Kalgora, 2016). Human resource (HR) practitioners are challenged to design performance management systems (PMS) that support organisational goals (Armstrong, 2014; Mwangi \& Njuguna, 2019).

In response to the government call to improve employee performance, Harare City Council (HCC) introduced a PMS in 2005 that uses the integrated results based management (IRBM) as a performance tool (Chimbabkwe, 2016). Integrated results based management is performance management (PM) tool designed for the public sector (Mayne, 2004; Zinyama, Nhema, \& Mutandwa, 2015). Substantial resources were committed to PM activities since the introduction of IRBM (Ruwende, 2017). However, there is no change in employee performance (Chihambakwe, 2016). Poor service delivery, corruption, high turnover of critical skills and employee strike action have become the hallmark on the face of the once famed 'Sunshine City' (Poperwi, 2018). Bandauko (2018) argued that HCC requires PM reforms to improve employee performance.

Urban dwellers expect value for their money. Meanwhile, cities are located at the nexus of driving service delivery and should accordingly capacitate their employees to respond to the expectations of the wider stakeholder community (Chirasha, Chipunza, \& Dzimbiri, 2017; 
Poperwi, 2018). However, the quality of service delivery in most urban centres in Zimbabwe has been deteriorating since the turn of the century (Chigudu, 2014; Chigunwe, Kudenga, \& Chigunwe, 2016). Poor service is attributed to poor employee performance (Chigunwe et al., 2016). It is, therefore, justifiable to conduct an inquiry that seeks to address employee performance deficiencies at HCC.

This study examined the PM practices employed by HCC to improve employee performance. In other words, the study seeks to answer the question: What are the practises that may improve employee performance at HCC?

\section{Research purpose and objectives}

The study seeks to identify practises that may improve employee performance at HCC. The research purpose will be achieved by pursuing two objectives, namely (1) to identify the challenges hindering the successful implementation of the PM and (2) to determine practices that support the improvement of employee performance.

\section{Literature review}

Performance management is defined as a process that seeks to align employee contribution to the strategic goals of the organisation (Aguinis, 2019; Armstrong, 2014). Performance management assists employees to achieve the strategic business objectives (Ryazanova, McNamara, \& Aguinis, 2017). Salah (2016) explained PM reinforces behaviours consistent with the attainment of organisational goals and sanctions negative behaviours. Another function of the PM system derived from its description is that it serves to furnish management with valid and useful information in making administrative decisions (Armstrong, 2014; Mwangi \& Njuguna, 2019).

Effective performance can be achieved if line managers recognise that human beings are not machines, rather they have emotions and needs (Al Salman \& Hassan, 2016). Unlike other resources, HRs have feelings; therefore, the impact of employee motivation on performance cannot be questioned (Cloutier, Felusiak, Hill, \& Pemberton-Jones, 2015).

In concurrence with this view, some scholars in organisational behaviour have developed theories that explain the factors that impact the employee performance in the organisational goals (Adams, 1965; Adelfer, 1972; Aruma \& Hanachor, 2017; Herzberg, Mausner, \& Snyderman, 1957; Latham \& Locke, 1979; Maslow, 1954; Vroom, 1964). This study, therefore, unpacks various perspectives that could inform practises to improve employee performance at HCC.

Storey (1989) described the spectrum of HR issues as hard and soft approaches. An analysis of the two approaches reveals that both the hard and the soft approaches seek to enhance employee performance but in different ways (Armstrong, 2014). The hard approach maintains a rigid focus on business interests (Boon, Eckardt, Lepak, \&
Boselie, 2018; Plaskoff, 2017). On the other hand, the soft approach is sensitive to human needs and achieves high employee performance through practices that motivate employees(Saad, 2018). However, following the soft approach alone can result in a high-cost structure, which is not sustainable for the business (Hecklau, Galeitzke, Flachs, \& Kohl, 2016; Plaskoff, 2017). Therefore, achieving a balance between the two extremes is critical for sustainability (Hamid et al., 2019; Hecklau et al., 2016; Kumari \& Singh, 2018).

Under the desire to identify the human needs that drive employee performance, Maslow in 1954 posited that human needs exist in the form of a hierarchical pyramid (Aruma \& Hanachor, 2017). Maslow (1954) argued that employee performance can be stimulated by matching rewards to individual need levels on the pyramid (Ma'ruf, Hadari, \& Amalia, 2019). The limitations of the needs theory are that it is difficult to defend the existence of the hierarchical structure of needs in all people (Kuvaas, Buch, Weibel, Dysvik, \& Nerstad, 2017; Saad, 2018). Maslow's theory suggests that individuals seek to satisfy one need level at a time; however, this assertion is difficult to prove as human behaviour is too complex to accept such an assumption (Saad, 2018). It informs line managers' decisions on the best way to reward individual employees to stimulate improved performance.

In an effort to close the gaps in Maslow's theory, Alderfer proposed the existence relatedness and growth (ERG) theory (Armstrong, 2014). The ERG theory rearranged the hierarchy pyramid by collapsing it into three categories to close overlaps between need levels (Alderfer, 1972). The ERG accepts the simultaneous existence of needs in employees and asserts that the order of needs should not be the same for all people. Furthermore, if one is frustrated by the failure to achieve a higher level need, he may regress to a lower level need. The ERG theory can be viewed as a more accommodative perception than the hierarchy of needs (Armstrong, 2014).

Implications for management are that line managers should stimulate employee performance by satisfying the multiple needs in employees (Kuranchie-Mensah \& Amponsah-Tawiah, 2016). Furthermore, employees should be sufficiently capacitated in time to prepare themselves for possible future challenges associated with higher-order needs. This helps to avoid employee frustration that can arise when they fail to achieve growth needs, thereby resulting in diminished performance.

In another theory of motivation, Douglas McGregor coined a theory X and theory $\mathrm{Y}$ of motivation (Kuranchie-Mensah \& Amponsah-Tawiah, 2016). McGregor (1960) argued that in both theory $\mathrm{X}$ and $\mathrm{Y}$, management has a central role in bringing together factors of production to enhance performance. In theory $X$, he posited a negative view on human behaviour and argued that human beings dislike work and will not perform unless they are forced (Al Salman \& Hassan, 2016). Theory $X$ links the command and control style of leadership to the lower order needs in the Maslow's 
pyramid as the only available sources of motivation (Kuranchie-Mensah \& Amponsah-Tawiah, 2016). However, an analysis from this view shows that in modern societies the lower order needs are already satisfied. Therefore, it gives the implication that modern day employees have no motivation to work. From that rational, he further proposes theory $\mathrm{Y}$ as an alternative theory. He argued that human beings are naturally inclined to love work, motivation increases if higher-order needs are addressed and people are innovative and can handle responsibility. Management implications for theory $\mathrm{Y}$ are that line managers can assist their employees to reach their full potential by employing various techniques such as delegation, job enlargement, participative management and performance appraisal. If the correct environment is created, employees will do everything within their ability to achieve high-performance levels (Osborne \& Hammoud, 2017).

From another perspective, Herzberg (1968) proposed the hygiene-motivation two-factor theory and argues that employee performance is a function of their motivation. Herzberg (1968) identified the motivators as factors that cause satisfaction and these emanate from the work itself. On the other hand, the hygiene factors emanate from the external environment and can lead to dissatisfaction (Kuvaas et al., 2017).

The motivators have a long-term effect in stimulating employee performance whilst the influence of the hygiene factors is short-lived. The traditional methods of rewarding good performance centred on hygiene factors such as high salaries and improved working conditions. However, contemporary research has shown that hygiene factors on their own cannot sustain high levels of performance in the long term (Kuvaas et al., 2017; Salah, 2016). Hygiene factors are subject to the dictates of various environmental factors that are sometimes beyond control, whilst motivators are a function of an individual's will power and, therefore, sustainable (Howard, Gagne, Morin, \& Van Den Broeck, 2016). Therefore, motivators should form part of the critical part of the job design (Salah, 2016).

Implications to line managers are that jobs should be designed to continuously challenge the employee to fully utilise the potential. Although hygiene factors should not be eliminated, they should be complemented with motivators to maximise employee performance. Job enrichment should remain as part of an ongoing management process (Herzberg et al., 1957). High achievers should be given tasks that match their levels of competency. Therefore, when the job seizes to be challenging, the employee should be replaced by a machine or by other less skilled employee.

Herzberg's theory of motivation has been criticized for assuming that the relationship between job satisfaction and performance is strong in all cases (Ma'ruf et al., 2019). Furthermore, human beings are naturally inclined to take credit for satisfaction and lay the blame for dissatisfaction on external factors that brings to test the validity of the earlier claim that motivators inspire performance better than hygiene factors.

In another view, the cognitive evaluation theory (CET) by Deci (1975) argued that intrinsic motivation is influenced by external environment. Therefore, the implication to line managers is that they should create an environment that is conducive for employees to perform with commitment. In line with the views on the relationship between the external environment and employee performance, Skinner (1974) proposed the reinforcement theory. The reinforcement theory states that an individual's behaviour is shaped by the consequences that follow his or her actions. Skinner (1974) argued that behaviour that is followed by positive consequences tend to be repeated whilst behaviour that is followed by negative consequences is eliminated. The theory, therefore, overlooks the internal state of mind. The implications for line managers are that rewards should be structured in such a way that they reinforce the desired performance outcome or eliminate unwanted behaviour. Line managers should, therefore, continuously provide feedback on employee performance and clarify their expectations.

Chordiya, Sabharwal and Goodman (2017) argued that all performance interventions could not succeed without top management's support. The importance of top management commitment in driving performance improvement is well acknowledged in literature (Kanwal, Zafar, \& Bashir, 2017; Nazir \& Islam, 2017; Nazir, Shafi, Qun, Nazir, \& Tran, 2016). Top managers drive performance by communicating the organisational goals, resourcing the change effort and monitoring the resource utilisation (Nazir et al., 2016). When top managers are not committed to PM, general employee performance outputs diminish (Kanwal et al., 2017). Galletta et al. (2019) argued that when the commitment profiles interact positively, the level of employee commitment towards performance increases. In any case, performance must not be induced by rules but should be driven by commitment (Nkhukhu-Orlando, Brow, Wilson, Forcheh, Linn, \& Fako, 2019).

In another observation, the indicators of poor employee commitment include high absenteeism (Miraglia \& Johns, 2016). However, new evidence indicates that presenteeism has the same negative effect on performance as absenteeism (Sermanet, Xu, \& Levine, 2019). Presenteeism is when work attendance is high, but employees engage in unethical behaviours such as theft and corruption (Pohling, Buruck, Jungbauer, \& Leiter, 2016). Unethical employee behaviours have far-reaching consequences in the public sector as they tarnish the image of the organisation and destroy stakeholder's confidence (Tonelli, De Souza Bermejo, Aparecida Dos Santos, Zuppo, \& Zambalde, 2017). Both absenteeism and presenteeism hinder performance and organisational growth (Miraglia \& Johns, 2016; Pohling et al., 2016). 
Sun and Bunchapattanasakda (2019) argued that it is important for organisations to offer competitive employee value propositions to minimise incidents of absenteeism and presenteeism. An organisation that has a behaved workforce is more attractive as an employer of choice than an organisation that has multiple disciplinary issues (Kossivi, Xu, \& Kalgora, 2016; Naim \& Lenka, 2018). A stable industrial relations climate is, therefore, conducive for performance improvement.

In an attempt to further understand the drivers of employee performance, Vroom (1964) in his expectancy theory asserted that employees work hard if they can achieve the set goals and receive rewards that they value (Luneburg, 2011; Miraglia \& Johns, 2016). It, therefore, implies that line managers should set achievable goals, provide rewards on successful performance and provide rewards that have value to the employee. In line with the link between performance and rewards, Adams (1963) proposed the equity theory. The theory argues that employees apply the effort that they perceive to be fair in relation to their effort. In assessing the fairness of their rewards employees compares their earnings with similarly placed professionals. When there is an imbalance employee feel unfairly treated and, therefore, diminish their effort in protest of the unfairness (Kuvaas et al., 2017).

Training and development play a key role in improving employee competencies to perform (Jang, Lee, Hwang, \& Shin, 2019). Primarily training seeks to improve attitudes, skills and knowledge (Armstrong \& Landers, 2018). Although motivation and rewards influence employee attitudes to perform, the skills and knowledge can be enriched by training processes (Jang et al., 2019). Sharma and Taneja (2018) accepted that training has a major role in equipping employees with the relevant skills to enhance performance. Skinner (1974) asserted that employee training is part of positive reinforcement that seeks to enhance improved performance. However, training becomes relevant when it is based on identified needs as opposed to routine training programmes (Grespan, Fioring, \& Collucci, 2019; Phillips, 2016; Sharma \& Taneja, 2018)

Organisations should not underestimate the impact of change on employee performance (Petrou, Demerouti, \& Schaufeli, 2018; Rebeka \& Indradevi, 2017). When change is mismanaged employees tend to resist the intervention and this can manifest through poor performance (Douglas, Muturi, \& Douglas, 2017). Lewin (1947) in his change theory argued that the change process should involve unfreezing, changing and refreezing. The systematic management of the change process minimises resistance to change and supports the attainment of the performance goals (Rebeka \& Indradevi, 2017; Shah, Irani, \& Sharif, 2017). Use of change agents assists in maintaining high-performance levels during the change process (Rangus \& Slavec, 2017; Rebeka \& Indradevi, 2017). Ochurub, Bussin and Goosen (2012) accepted the notion of using change agents and further emphasised on the importance of involving the employees in developing performance strategies during the change process.

Given the various theories provided in the literature to explain the performance concept Aguinis (2019) argued that HR practices play a pivotal role in enhancing employee performance.

\section{Research design}

This section describes the components that form the blueprint for managing the data that was used in the study to address the research problem.

\section{Research approach}

The study adopted the qualitative methodology that relies on the interpretivist paradigm. The interpretivist approach was preferred because it is pragmatic and reveals the truth about lived experiences (Merriam, 1998). It enhances the understanding of employees' views and experiences in implementing PM. The researcher gained first-hand knowledge from the participants' expressions. This influenced interpretations of how to reframe current Human Resources Management (HRM) practices to improve employee performance. The interpretive approach is concerned about the quality and texture of life rather than frequency of occurrence (Yin, 2009). The ontological and epistemological views accepted the plurality of reality, the importance of social interactions in unearthing the unknown realities (Merriam, 1998). Furthermore, the study embraced the importance of interaction and engaging participants to understand their experiences (Creswell, 2014). The study rejects the notion of objectivity in life and places emphasis on deriving meaning from understanding the perceptions of the affected individuals (Merriam, 1998). Therefore, the researcher was not a detached object but actively engaged the participants (Creswell, 2014). The researcher's prior knowledge of the municipal environment contributed to derive the interpretation of the research findings (Miles, \& Huberman, 1994).

\section{Research strategy}

The study utilised a case study method to understand in detail the challenges faced by the participants and develop solutions for the chosen case (Farquhar, 2012). The case study focused on employee performance deficiencies at HCC, hence interviewed participants within their natural setting.

\section{Research method}

The study used a qualitative method because the primary intention was to obtain a detailed description and understanding of the challenges at HCC (Babbie \& Mouton, 2001). The information gained informed the recommendations made for improving PM praxis at HCC. The qualitative method was, therefore, the most appropriate method as it resonates with the purpose of the study, which is to discover 
better ways of improving employee performance. It permitted the emergent existence of unknown realities and created room for new thinking, unlike the quantitative that is prefigured and restricted to what is already known (Yin, 2009).

\section{Research setting}

In line with the requirements of the qualitative methodology, the study was conducted in its natural setting (Bhattacharya, 2008). The study was conducted at a municipal establishment in Zimbabwe. Harare City Council adopted IRBM on a trial basis in 2005 (Ngwenyama, 2014). The implementation was scaled up for full implementation in 2013 as a public sector PM tool (Chilunjika, 2016). However, the city is struggling to improve employee performance and to operationalise the IRBM. Therefore, the researcher engaged HCC employees to gain familiarity with the challenges faced and recommended practices that could improve PM.

\section{Entrée and establishing researcher roles}

The researcher applied to seek permission from the highest authority at HCC to be allowed to access the interview participants (Creswell, 2014). An application was made to the Town Clerk and permission was granted. The researcher drafted an agreement with binding terms between himself and the organisation, which outlined the research process, projected impact on the employees and the organisation, specific researcher roles, projected timelines, handling of findings and possible benefits of the study.

\section{Research participants and sampling methods}

Harare City Council has a total population of approximately 10000 employees. Purposive sampling was used to target potential rich sources of data. The identified sample comprised five managerial and five non-managerial employees who have been in the organisation since the IRBM was introduced. The decision to use managers and non-managers assisted in obtaining balanced views from both classes of employees. Importantly, participants were not merely chosen to represent a dominant opinion but to enrich the inquiry under their knowledge and experience (Merriam, 1998).

\section{Data collection methods}

Semi-structured interviews were conducted with the participants. The semi-structured interviews have unique strengths in the sense that they allow all participants to respond to the same set of questions, at the same time providing the flexibility to probe emerging issues (Merriam, 1998; Miles \& Huberman, 1994).

\section{Data recording}

The researcher employed the services of experts for audiorecording and transcribing the verbatim responses. The use of experts in data recording allowed for speedy and professional recording of the interview responses (Yin, 2009). Furthermore, it allowed the researcher to concentrate on the interview process with minimum disruptions (Neuman, 2003).

\section{Strategies employed to ensure data quality and integrity}

Participants were allowed to read through the collected interview data and sign off to acknowledge authenticity before and after interpretation (Yin, 2009). Any doubtful information and ambiguities were cleared (Neuman, 2003). The researcher familiarised himself with participants before interviewing them to gain their trust. The participants were reassured of the confidentiality of the information (Yin, 2009). Furthermore, before conducting the interview, the researcher attended a professional interview skills course to equip himself with the relevant knowledge and skills that enabled him to conduct the interviews competently. Sources of data were triangulated by interviewing both managerial and non-managerial employees. To minimise bias in data coding, the researcher employed the services of an experienced researcher to review the coded data and his comments were incorporated to enrich the data quality (Miles \& Huberman, 1994).

\section{Data analysis}

The ATLAS.ti was used to analyse the interview data. The collected data for each objective was retrieved and classified into manageable sizes. The data groups were coded to create identity marks of commonalities. Themes were developed by sorting the data with commonalities into categories and sub-categories that show relationships and links in a format that permitted the drawing of conclusions. Special attention was given to both semantic and latent level of analysis (Yin, 2009). The themes that directly responded to the research questions were embraced whilst deviant cases were analysed to check for any relevance to the phenomenon under study. Field notes were regularly referred to and participants were consulted to verify conformity of the interpretations to the original data.

\section{Reporting style}

The revealed themes were summarised in line with the study objectives. The literature on the themes was explored and supporting theories were examined to check agreements and disagreements with the new findings as they relate to the study. Consequently, conclusions and recommendations were made to achieve the research purpose.

\section{Ethical consideration}

The ethical clearance to conduct this study was obtained from the University of Johannesburg, Ethical clearance code: IPPM-2018-169(D). 


\section{Results}

The findings revealed three themes, namely motivation to perform, institutional factors and training and development as outlined in this section.

\section{Motivation to perform}

The theme poor motivation to perform was supported by five codes as shown in Figure 1 code network.

Low morale: Some participants indicated that they are not happy because of the poor grievance handling practices in the organisation:

'In this organisation nobody cares to address our grievances, as I speak we are working with no protective clothing, our salaries are in six months arrears so our morale is low but our supervisors insist on achieving targets.'

Management explained that it is difficult to sustain morale because everyone is demotivated including the supervisors. One non-managerial employee, however, indicated that the organisation does not have any clear grievance handling procedure and the line managers are insensitive.

However, an unexpected finding was that the labour turnover for non-managerial employees was very low despite the low morale. Furthermore, probing revealed that the low turnover is because of high unemployment in the economy and the employees stay because they cannot make alternative employment in the country. However, other young professionals insisted that they are not leaving the organisation because it gives them the practical exposure they require for professional growth and this would enable them to find more paying jobs in future. As a result, the organisation was left with poorly skilled and less knowledgeable employees.
Poor readiness for change: The study found that the employees were poorly prepared for change when the new PM was introduced. Most employees were not consulted, but the government was anxious to see results in the shortest possible time:

'We were taken by surprise when the government directed us to use IRBM and we were inadequately prepared for it ... everything was rushed.'

'The effort could have yielded better results but the challenge is that it was imposed on us.'

'I think it is a waste of resources because the implementation was rushed ... the authorities expected an overnight change in employee behaviour without establishing the fundamentals that are important for change to happen.'

'The organisation is ill prepared for change, the supervisor lack the required competencies to implement PM.'

The findings revealed that employees are not ready to accept the new PM. The organisation did not prepare the employees for the new PM tool; hence, some employees have a negative attitude towards PM issues.

Lack of top management commitment: The top managers were accused for lacking commitment towards the PM:

'Top managers do not take the initiative to lead the process; they have negative attitudes towards the IRBM.'

The lack of commitment by top managers was viewed as the primary cause of implementation failure. The top managers revealed that they feel that the design of the PM instrument is inappropriate for the municipal environment. They accused the authorities for not involving them:

'The PM tool should have been designed to suit our context because our structure and operational dynamics are different from the rest of the civil service.'

There is no sense of ownership of the PM initiative, the majority of top managers are frustrated and are anxious to leave the

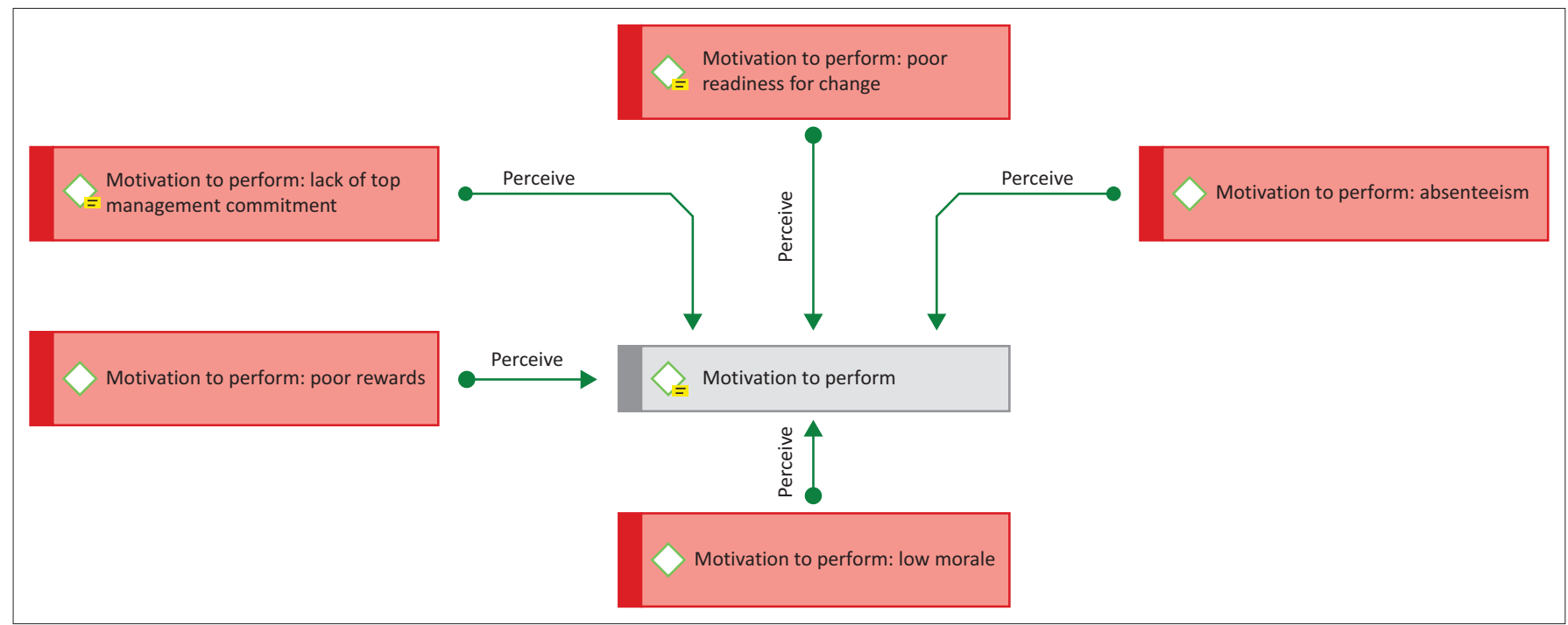

FIGURE 1: Code network for the theme employee motivation. 
organisation whenever opportunities arise. As a result, the organisational vision and strategy is weakly supported.

Poor rewards: Participants across the board concurred that there are no incentives to support the change initiatives:

'I do not understand the point of increasing my workload when there is no corresponding increase in rewards.' (P10, typist, female)

The new PM increased workload, but the organisation did not put incentives to encourage employees to increase effort. The participants indicated that the government instead used threats of victimisation against resistant employees. Good and bad performers are all treated the same.

High absenteeism: The interviews revealed that employees who work in areas where there is no room to engage in corruption have high absenteeism rates:

'My job as a nurse does not expose me to any form of corruption because I do not handle cash, so I do not report for duty every day I absent myself and find other part time work to supplement the meagre salaries that I get here.' (P9, nurse, female)

However, employees such as municipal police have minimum absenteeism reports, when the researcher probed to check the reasons, the findings revealed that the employees are known for soliciting bribes from motorists. One participant from the municipal police expressed himself as follows:

'I come to work every day because the money that I collect in bribes from the traffic offenders is far better than a manager's salary in this organisation ... I have no option, I do not care even if I get arrested because if I do not accept the bribes I will starve.' (P7, Municipal police officer, male)

The above expressions show that high absenteeism and corruption is being influenced by the poorly remunerated employees.

\section{Institutional factors}

The theme institutional factors emerged as another hindrance to performance improvement as shown in the code networks in Figure 2.

Involvement of elected officials in appraising employee performance: Managerial employees complained against the involvement of elected officials in their performance appraisals:

'Some of the elected officials lack basic education so it is wrong to expect them to appreciate the technical aspects of my job as a technocrat as a result their ratings are biased.'

The managers argued that whilst the representation of elected officials in their performance evaluation can be necessary, however, they need guidance whilst conducting the assessment process. The performance appraisal processes emerged as a source of conflict and industrial disharmony:

'There is no clear office of appeal whenever we have disputes with the councillors.'

The employees suggested the need to expand the grievance procedure to assist in settling disputes between senior managers and elected officials.

Poor Management of Information Systems: Participants argued that Management of Information System (MIS) is poor because it relies on manual methods. The performance records are compiled and kept in hard copy, which makes it difficult to retrieve:

'It requires a lot of time to be writing, filling and retrieving these hard copy files, at the end of the day you waste more time on filling than on the actual work.'

The interviews revealed that the HR information system is not integrated with the information technology (IT) grid to necessitate easy to access and analysis. Participants complained that many information from the performance

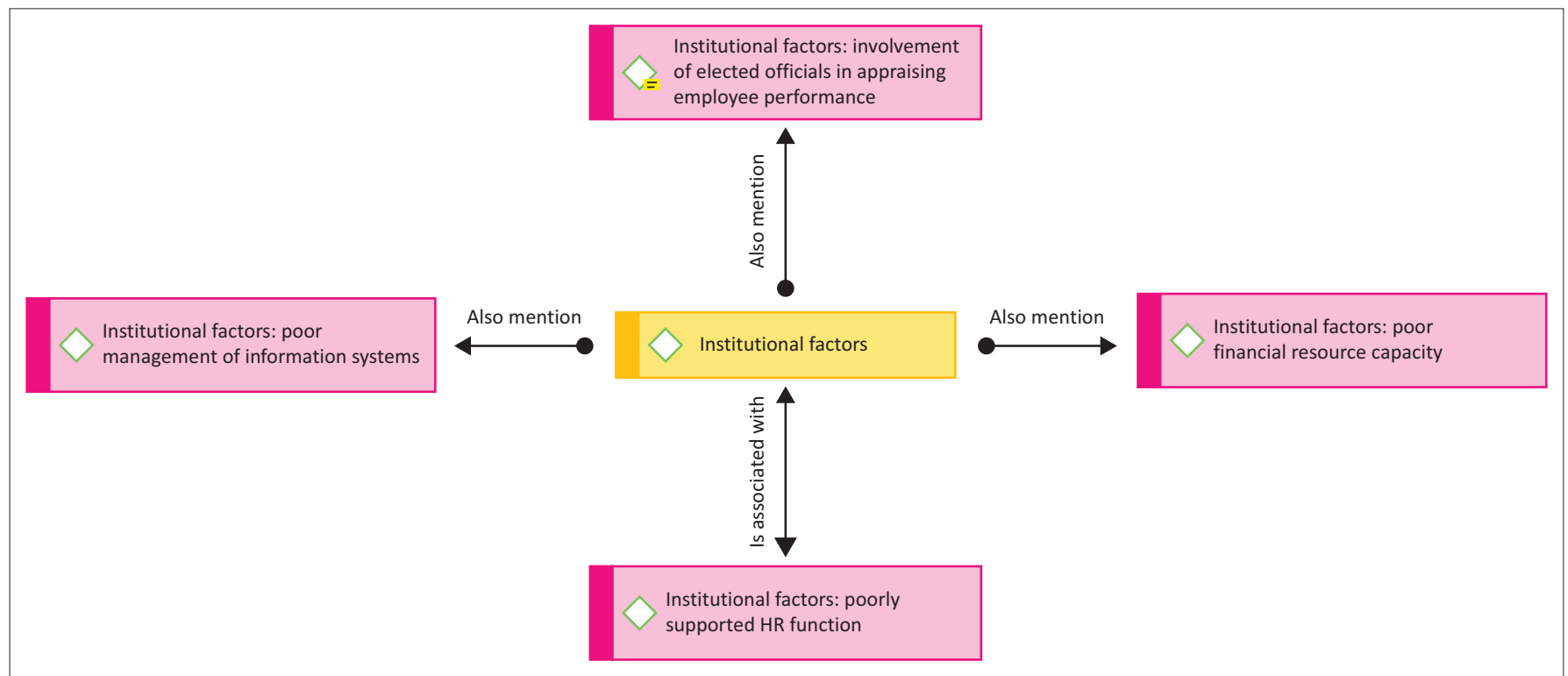

FIGURE 2: Code network for the theme institutional factors. HR, human resource. 
evaluation is lost because of the poor MIS. As a result, the performance ratings lack objectivity. In line with the noted deficient, non-managerial employees noted that they are prejudiced of the credit that they deserve. The whole PM system becomes a farce and employees lose interest in the process.

Poor financial resource capacity: Participants bemoaned the poor financial support for PM activities:

'The PM activities are poorly funded and the organisation cannot afford competitive salaries and incentives.' (Participant 1, Finance officer, Male)

Participants indicated that they were at one point promised incentives, but management failed to pay because of low revenue inflows compounded by the deteriorating economic environment that is characterised by a hyper inflationary environment. As a result, the employees have lost faith in their management:

'These managers are a bunch of liars, they promise one thing and do the opposite, so there is no need to kill yourself with work when you don't get any recognition.' (P6, Cleaner, Male)

The non-managerial employees feel that the PM was management's ploy to exploit employees by giving them false promises to work, yet they know that they are not able to fulfil the promises.

Poorly supported HR function: Participants noted that top management does not value the importance of the HR department:

'This organisation has gone for more than 3 years without a substantive head of $\mathrm{HR}$ and all HR activities are poorly resourced.' (P7, Human Resource Officer, Male)

The interviews revealed that the organisation does not value the HR function in the same way that other departments are valued as shown by the failure to support its requirements. As a result, it negatively impacts the departmental deliverables such as the implementation of the IRBM within the council.

\section{Training and development}

The theme emerged from an inquiry that sought to reveal the reasons for the employees' failure to operationalise the PM tool, although substantial investment had been made towards employee learning and development. The theme was supported by three codes as shown in the code network in Figure 3 below.

Employees' negative attitudes: The participants revealed that the employees have negative attitudes towards the PM. Training workshops on operationalising the IRBM were conducted, but knowledge accumulation is very low. Upon further probing, the participants revealed that employees could not relate their personal goals and ambitions to the PM goals:

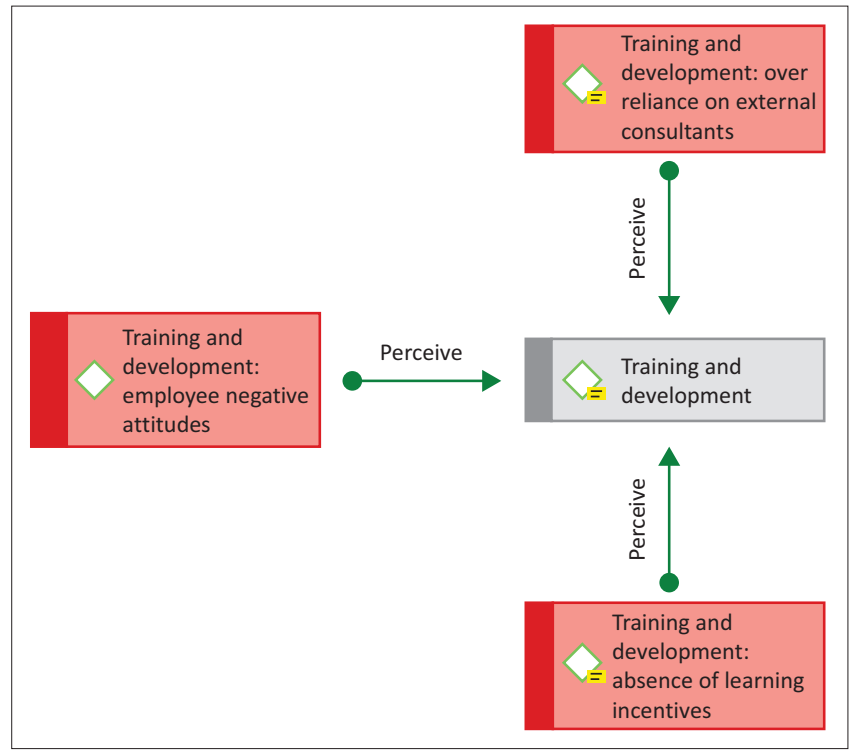

FIGURE 3: Code network for the theme training and development.

'It seems the PM is all about 'them' and not 'us' because it focuses on achieving organisational goals without any consideration on us as employees.'

The employees indicated that the PM goals should be redesigned to ensure that they balance organisational and employee goals.

Absence of learning incentives: The participants complained that the organisation does not have incentives for learners:

'What exactly do I benefit from learning IRBM and is there any reward for it?.' (P6, Cleaner, Male)

The interviews revealed that the organisation does not recognise the employees who show interest in acquiring new skills and knowledge. Participants argued that the organisation should explore options for both monetary and non-monetary rewards to motivate employees to learn. The participants further indicated that there are no training impact assessments, which are conducted after attending the training. As a result, employees cannot tell whether the training has benefited them or not.

Over reliance on external consultants: The organisation over relies on external consultants to lead the training sessions. Participants complained that some of the external consultants lack the municipal operational knowledge and their training is too theoretical:

'The external consultants have become a conduit for siphoning municipal coffers my brother. ... I do not see their value because their trainings are too theoretical.' (P7, Human Resource Officer, Male)

The non-managerial employees view external consultants as agents for siphoning municipal funds as most of them lack the required knowledge and expertise to train employees on performance issues. They recommend training programs to the train the trainer programmes to equip line managers to train others on the job, especially on the technical aspects of the IRBM tool. 


\section{Discussion Outline of results}

This section outlines the major findings as drawn from the objectives of the study.

\section{Factors that hinder the implementation of performance management}

The findings revealed that employees feel neglected as nobody cares to listen to their concerns. The organisation is concerned about achieving its strategic goals without considering human needs. Boon et al. (2018) argued that the hard approach to people management should not be taken to extremes as it has the effect of diminishing employee loyalty and commitment towards the organisation. Storey (1989) acknowledged the negative effects that the hard approach can have on employee performance. Al Salman and Hassan (2016) found that unlike machines, human beings have a soft part that requires attention, therefore, when management fails to recognise their needs, they express their frustration through poor performance.

Other indicators of employee frustration are high absenteeism and unethical behaviours such as corruption. The findings are consistent with the observations made by Sun and Bunchapattanasakda (2019), who argued that if employees are poorly remunerated, they engage in unethical behaviours such as moonlighting and corruption. Kuvaas et al. (2017) on their study on the link between employee motivation and performance outcomes found that poorly motivated employees are the worst performers. This finding is consistent with the current study findings that revealed that employee performance outcomes are diminishing by the day.

The interviews revealed that the reward structure does not recognise skill differences as all employees are treated the same as a result high performers are deteriorating. The findings can relate to the views of the equity theory as proposed by Adams (1963). Highly experienced employees feel unfairly treated, their frustration manifests through high turnover and poor performance. Vroom (1964) in his expectancy theory further argues that when the organisation fails to meet employee expectations they deliberately diminish their performance as a way of expressing their frustration.

The findings revealed that the environment within which HCC is operating has negative factors that impact on performance. The environment is characterised by a hyperinflationary environment, low revenue inflows, absence of a legal framework that govern the implementation of IRBM, absence of information communication technolgy to enhance efficiency in MIS. These environmental concerns are sources of employee stress and negatively impact on performance. Deci (1975) argued in his CET that events in the external environment can affect individual internal motivation to work. Skinner (1974) in his reinforcement theory contended that employee perfomance is largely influenced by the factors in the external environment. In support of the effect of the organisational climate on employee performance, Douglas et al. (2017) found that employee performance is a function of their environment. When the environment is stressing, they either decide to quit or engage in compensatory behaviour such as diminished performance.

\section{Factors that support the implementation of performance management}

The findings revealed that the transition of adopting the IRBM could be improved. It emerged that employees require involvement in developing performance improvement tools such as IRBM, they need incentives, and they develop negative attitudes if threats are used on them. Rebeka and Indradevi (2017) found that positive employee attitudes are critical for the successful implementation of any change effort. When employees are happy, they own the change process and perform well to prove that the change works. Lewin (1947) in his change theory, placed emphasis on the importance of managing the change process systematically, to enhance performance. The use of change agents and involvement of employees could enrich PM during the change process (Ochurub, Bussin and Goosen 2012; Rangus \& Slavec, 2017).

The findings revealed that training has a critical role of enhancing employee competencies to improve the implementation of PM. It was noted that whilst the HR department makes an effort to conduct the training needs, the actual training programs being conducted are not informed by the identified needs. Jang et al. (2019) argued that training helps to improve employee competencies which in turn impact on performance outcomes. Sharma and Taneja (2018) further confirmed that employees who are regularly trained can perform better than employees that are not trained. Jang et al. (2019) concurred with the observation by arguing that the learning curve can be shortened by using on-the-job training techniques under the guidance of coaches who have practical knowledge of the operations. The ultimate objective is to improve employee performance, therefore, the training environment should be as close as possible to reallife challenges (Phillips, 2016). Furthermore, there is a need to conduct training impact evaluation to assess the extent of knowledge transfer (Armstrong \& Landers, 2018).

\section{Practical implications of the study}

The study revealed that performance improvement interventions should always be implemented with a human face. Line managers should reward employees for their individual contribution as opposed to rewarding everyone the same. Goal achievement should be balanced between business interest and people needs, therefore, line managers should set performance objectives that recognise both interests.

Remuneration plays a key role in enhancing employee performance. When employees are poorly remunerated, 
they become frustrated and diminish their performance. Their minds become preoccupied with the fight for survival. Therefore, line managers can stimulate employee performance by paying a living wage. This should be supported by providing opportunities for growth to stimulate intrinsic motivation.

External environment impacts the employees' psychological state of mind. When employees are motivated, they become innovative and the quality of their performance outcomes improves. Line managers should create an environment that promotes a harmonious industrial relations climate.

Change management should be handled systematically to avoid diminishing employee performance. Line managers should prepare employees for change and support the change effort by offering relevant incentives. Factors that promote resistance to change should be suppressed to minimise employee resistance to change.

Employee training should be based on identified needs. Training and development should be an ongoing process throughout the entire life of an employee to keep the skills relevant to the new business challenges.

\section{Limitations and recommendations}

The study was confined to HCC and relied on a small sample. Future studies could focus on other settings to cover a wider geographic area to increase the generalisability of the findings. Future researchers may want to pursue a quantitative trajectory and test the cause and effect of the variables in the matrix of PM in local authorities.

The study further recommends that HCC fully implements the IRBM and supports it with training and relevant incentives. The HR function should take a leading role of coordinating performance improvement interventions. Given the hyperinflationary environment within which the municipality is operating, the line managers should explore other non-monetary rewards to enhance employee motivation.

\section{Conclusion}

The study revealed hindrances to the implementation of $\mathrm{PM}$ and further proposed practices that can inform the framework of PM at HCC.

Future researchers are challenged to explore other factors that may have a bearing on PM in local authorities.

\section{Acknowledgements Competing interests}

The authors have declared that no competing interest exists.

\section{Authors' contributions}

All authors contributed equally to this work.

\section{Funding information}

This research received no specific grant from any funding agency.

\section{Data availability statement}

Data sharing is not applicable to this article as no new data were created or analysed in this study.

\section{Disclaimer}

The views and opinions expressed in this article are those of the authors and do not necessarily reflect the official policy or position of any affiliated agency of the authors.

\section{References}

Adams, J.S. (1963). Toward an understanding of inequity. Journal of Abnormal and Social Psychology, 67(5), 422-436. https://doi.org/10.1037/h0040968

Adams, J.S. (1965). Inequity in social exchange. In L. Berkowitz (Ed.), Advances in experimental social psychology (Vol. 2, pp. 267-299). New York, NY: Academic Press.

Aguinis, H. (2019). Performance management for dummies. Hoboken, NJ: John Wiley \& Sons, Inc.

Alderfer, C. (1972). Existence, relatedness and growth. New York, NY: The Free Press.

Al Salman, W., \& Hassan, Z. (2016). Impact of effective teamwork on employee performance. International Journal of Accounting and Business Management, 4(1), 76-85. https://doi.org/10.24924/ijabm/2016.04/v4.iss1/76.85

Alderfer, C. (1972). Existence, relatedness and growth. New York, NY: The Free Press.

Armstrong, M. (2014). Handbook of human resource management in government. British Library Cataloguing-in-Publication Data, Philadelphia, PA : Kogan Page Ltd.

Armstrong, M.B., \& Landers, R.N. (2018). Gamification of employee training and development. International Journal of Training and Development, 22(2), 162-169. https://doi.org/10.1111/ijtd.12124

Aruma, E.O., \& Enwuvesi Hanachor, M. (2017). Abraham Maslow's hierarchy of needs and assessment of needs in community development. International Journal of Development and Economic Sustainability, 5(7), 15-27.

Babbie, E., \& Mutton, J. (2001). The practice of social research. Cape Town: Oxford University Press.

Bandauko, E. (2018). Strategic planning in the City of Harare: What went wrong and what needs to be fixed? Spiked. Retrieved from https://spiked.co.zW/

Bhattacharya, H. (2008). Research setting. In L.M. Given (Ed.), The Sage encyclopedia of qualitative research methods (pp. 254-255). Thousand Oaks, CA: Sage.

Boon, C., Eckardt, R., Lepak, D.P., \& Boselie, P. (2018). Integrating strategic human capital and strategic human resource management. International Journal of
Human Resource Management, 29(1), 34-67. https://doi.org/10.1080/09585192 .2017 .1380063

Chigudu, D. (2014). Implementing new public management in Zimbabwe: Challenges and obstacles. Journal of Governance and Regulation, 3(2), 43-49. https://doi. org/10.22495/jgr_v3_i2_c1_p4

Chigunwe, T., Kudenga, M., \& Chigunwe, G. (2016). Opinions of residents on loca government practices and service priorities vis-a-vis actual delivery by local authorities: A case of Bindura, Zimbabwe. International Journal of Scientific and Research publications, 6(9), 579-584

Chihambakwe, W. (2016). The effectiveness of management strategies in local authorities in Zimbabwe: A case study of Harare City Council. Scholars Journal of Arts, Humanities and Social Sciences, 4(11), 1381-1387. https://doi.org/10.21276/ sjahss.2016.4.11.4

Chilunjika, A. (2016). Assessing the operationalisation of the results based management approach in the Ministry of transport, communication and infrastructural development in Zimbabwe. Public Policy and Administration Rresearch, 6(6), 1-12.

Chirasha, V., Chipunza, C., \& Dzimbiri, L. (2017). Self versus employees' Appraisal of managers' emotional intelligence: The case of Gweru and Kwekwe city councils, Midlands Province, Zimbabwe (pp. 180-200). The Dyke: Special edition. Retrieved from https://hdl.handle.net/11408/1848

Chordiya, R., Sabharwal, M., \& Goodman, D. (2017). Affective organizational commitment and job satisfaction: A cross-national comparative study. Public Administration, 95(1), 178-195. https://doi.org/10.1111/padm.12306

Cloutier, O., Felusiak, L., Hill, C., \& Pemberton-Jones, E. (2015). The importance of developing strategies for employee retention. Journal of Leadership, Accountability and Ethics, 12(2), 119-129. 
Creswell, J.W. (2014). Research design: Qualitative, quantitative and mixed methods approaches (4th edn.). Thousand Oaks, CA: Sage.

Douglas, J., Muturi, D., Douglas, A., \& Ochieng, J. (2017). The role of organisational climate in readiness for change to lean six sigma. The TQM Journal, 29(5), 1754-2731. https://doi.org/10.1108/TQM-04-2017-0046

Deci, E.L. (1975). Intrinsic motivation. Plenum Press.

Esther, N-O., Byron, B., Debra, R.W., Ntonghanwah, F., James, G.L., \& Thabo, T.F. (2019). The affective commitment of academics in a university in Botswana. International Journal of Educational Administration and Policy Studies, 11(2), 12-19. https://doi.org/10.5897/ijeaps2019.0595

Farquhar, J.D. (2012). Case study research for business. London: Sage.

Galletta, M., Portoghese, I., Melis, P., Gonzalez, C.I.A., Finco, G., D’Aloja, E., Campagna, M. (2019). The role of collective affective commitment in the relationship between work-family conflict and emotional exhaustion among nurses: A multilevel modeling approach. BMC Nursing, 18(1). https://doi. nurses: A multilevel modeling
org/10.1186/s12912-019-0329-z

Grespan, L., Fiorini, P., \& Colucci, G. (Eds.). (2019). Training. In The route to patient safety in robotic surgery: Springer tracts in advanced robotics (Vol. 126, pp. 143-148). Cham: Springer.

Hamid, Z., Muzamil, M., \& Shah, S.A. (Eds.). (2019). Strategic human resource management. In Handbook of research on positive organizational behavior for improved workplace performance (pp. 260-275). Hershey, PA: IGI Global.

Hecklau, F., Galeitzke, M., Flachs, S., \& Kohl, H. (2016). Holistic approach for human resource management in industry 4.0. Procedia CIRP, 54, 1-6. https://doi. org/10.1016/j.procir.2016.05.102

Herzberg, F. (1968). One more time: How do you motivate employees? (pp. 109-120). Boston, MA: Harvard Business Review.

Herzberg, F.W., Mausner, B., \& Snyderman, B. (1957). The motivation to work. New York, NY: Wiley.

Howard, J., Gagné, M., Morin, A.J.S., \& Van Den Broeck, A. (2016). Motivation profiles at work: A self-determination theory approach. Journal of Vocational Behavior 95-96, 74-89. https://doi.org/10.1016/j.jvb.2016.07.004

Jang, Y., Lee, H., Hwang, S.J., \& Shin, J. (2019). Learning what and where to transfer. In 36th International Conference on Machine Learning, ICML 2019 (Vol. 2019-June, pp. 5360-5369). International Machine Learning Society (IMLS).

Kanwal, N., Zafar, M.S., \& Bashir, S. (2017). The combined effects of manageria control, resource commitment, and top management support on the successful delivery of information systems projects. International Journal of Project Management, 35(8), 1459-1465. https://doi.org/10.1016/j.ijproman.2017. 08.007

Kossivi, B., Xu, M., \& Kalgora, B. (2016). Study on determining factors of employee retention. Open Journal of Social Sciences, 4(5), 261-268. https://doi.org/10.4236/ jss.2016.45029

Kumari, N., \& Singh, D. (2018). Impact of organizational culture on employee performance. Prabandhan: Indian Journal of Management, 11(6), 53-63. https:// doi.org/10.17010/pijom/2018/v11i6/128442

Kuranchie-Mensah, E.B., \& Amponsah-Tawiah, K. (2016). Employee motivation and work performance: A comparative study of mining companies in Ghana. Journal of Industrial Engineering and Management, 9(2), 255-309. https://doi.org/10.3926/ jiem.1530

Kuvaas, B., Buch, R., Weibel, A., Dysvik, A., \& Nerstad, C.G.L. (2017). Do intrinsic and extrinsic motivation relate differently to employee outcomes? Journal of Economic Psychology, 61, 244-258. https://doi.org/10.1016/j.joep.2017.05.004

Latham, G., \& Locke, R. (1979). Goal setting - A motivational technique that works. Organizational Dynamics, 8(2), 68-80. https://doi.org/10.1016/00902616(79)90032-9

Lewin, K. (1947). Frontiers in group dynamics. Human Relations, 1(1), 5-42. https:// doi.org/10.1177\%2F001872674700100103

Lunenburg, F.C. (2011). Expectancy theory of motivation: Motivating by altering expectations. International Journal of Management, Business, and Administration 15(1), 1-6

Ma'ruf, F., Hadari, I.R., \& Amalia, D. (2019). Employee motivation and performance models. International Review of Management and Marketing, 9(6), 80-86. https://doi.org/10.32479/irmm.8811

Maslow, A. (1954). Motivation and personality, New York, NY: Harper \& Row.

Mayne, J. (2004). Reporting on outcomes: Setting performance expectations and telling performance stories. Canadian Journal of program evaluation, 19(1), 31-60.

McGregor, D. (1960). The human side of enterprise. New York, NY: McGraw-Hill.

Merriam, S. (1998). Qualitative research and case study applications in education. San Fransisco, CA: Jossey-Bass.

Miles, M., \& Huberman, A. (1994). Qualitative data analysis. Thousand Oaks, CA: Sage.

Miraglia, M., \& Johns, G. (2016). Going to work ill: A meta-analysis of the correlates of presenteeism and a dual-path model. Journal of Occupational Health Psychology, 21(3), 261-283. https://doi.org/10.1037/ocp0000015

Mwangi, B.W., \& Njuguna, R. (2019). Performance appraisal strategies on performance of teachers in public secondary schools in Kiambu County, Kenya. International Journal of Current Aspects, 3(11), 218-230. https://doi.org/10.35942/ijcab.v3iii.19

Naim, M.F., \& Lenka, U. (2018). Development and retention of generation $Y$ employees: A conceptual framework. Employee Relations, 40(2), 433-455. https://doi.org/10.1108/ER-09-2016-0172
Nazir, O., \& Islam, J.U. (2017). Enhancing organizational commitment and employee performance through employee engagement: An empirical check. South Asian performance through employee engagement: An empirical check. South Asian
Journal of Business Studies, 6(1), 98-114. https://doi.org/10.1108/SAJBS-04Journal of

Nazir, S., Shafi, A., Qun, W., Nazir, N., \& Tran, Q.D. (2016). Influence of organizational rewards on organizational commitment and turnover intentions. Employee Relations, 38(4), 596-619. https://doi.org/10.1108/ER-12-2014-0150

Neuman, W.L. (2003). Social research methods: Qualitative and quantitative approaches. Boston, MA: Allyn \& Bacon.

Ngwenyama, P. (2014). An evaluation of the effectiveness of a performance management system towards employee performance in a Local Authority. The case of City of Harare from 2009 to 2013. Unpublished Masters dissertation. University of Zimbabwe, Zimbabwe.

Nkhukhu-Orlando, E., Brown, B., Wilson, D. R., Forcheh, N., Linn, J. G., \& Fako, T. T. (2019). The affective commitment of academics in a university in Botswana. International Journal of Educational Administration and Policy Studies, 11(2), 12-19.

Ochurub, M., Bussin, M., \& Goosen, X. (2012). Organisational readiness for introducing a performance management system. SA Journal of Human Resource Management/ SA Tydskrif vir Menslikehulpbronbestuur, 10(1), Art. \#389, 11 pages. https://doi. org/10.4102/sajhrm.v10i1.389

Osborne, S., \& Hammoud, M.S. (2017). Effective employee engagement in the workplace. International Journal of Applied Management and Technology, 16(1), 50-67. https://doi.org/10.5590/ijamt.2017.16.1.04

Organizational Dynamics, Autumn, pp 68-80

Petrou, P., Demerouti, E., \& Schaufeli, W.B. (2018). Crafting the change: The role of employee job crafting behaviors for successful organizational change. Journal of Management, 44(5), 1766-1792. https://doi.org/10.1177/0149206315624961

Phillips, J.J. (2016). Handbook of training evaluation and measurement methods. London: Routledge.

Plaskoff, J. (2017). Employee experience: The new human resource management approach. Strategic HR Review, 16(3), 136-141. https://doi.org/10.1108/shr-12-
2016-0108

Pohling, R., Buruck, G., Jungbauer, K.L., \& Leiter, M.P. (2016). Work-related factors of presenteeism: The mediating role of mental and physical health. Journal of
Occupational Health Psychology, 21(2), 220-234. https://doi.org/10.1037/ Occupation
a0039670

Poperwi, L. (2018). Making sense of poor service delivery in Harare City Council. Unpublished doctoral thesis. Harare: Zimbabwe Open University.

Rangus, K., \& Slavec, A. (2017). The interplay of decentralization, employee involvement and absorptive capacity on firms' innovation and business performance. Technological Forecasting and Social Change, 120, 195-203. performance. Technological Forecasting and
https://doi.org/10.1016/j.techfore.2016.12.017

Rebeka, E., \& Indradevi, R. (2017). Employees attitude towards organizational change. Man in India, 97(4), 99-106.

Ruwende, I. (2017, 24 May). Performance contracts for town council heads. Retrieved from http://www.herald.co.zw/

Ryazanova, O., McNamara, P., \& Aguinis, H. (2017). Research performance as a quality signal in international labor markets: Visibility of business schools worldwide through a global research performance system. Journal of World Business, 52(6) 831-841. https://doi.org/10.1016/j.jwb.2017.09.003

Saad, D.D.M.Z.b.S. (2018). Impact of employee motivation on work performance. International Journal of Scientific and Research Publications (IJSRP), 8(3), 295-308. https://doi.org/10.29322/ijsrp.8.3.2018.p7544

Salah, M. (2016). The influence of rewards on employees performance. British Journal of Economics, Management \& Trade, 13(4), 1-25. https://doi.org/10.9734/ bjemt/2016/25822

Sermanet, P., Xu, K., \& Levine, S. (2019). Unsupervised perceptual rewards for imitation learning. 5th International Conference on Learning Representations, ICLR 2017-Workshop Track Proceedings, 24-26 April 2017, Toulon, France.

Shah, N., Irani, Z., \& Sharif, A.M. (2017). Big data in an HR context: Exploring organizational change readiness, employee attitudes and behaviors. Journal of Business Research, 70, 366-378. https://doi.org/10.1016/j.jbusres.2016.08.010

Sharma, S., \& Taneja, M. (2018). The effect of training on employee performance. International Journal of Recent Technology and Engineering, 2(2), 52-59. https:// doi.org/10.31104/jsab.v2i2.49

Skinner, B.F. (1974). About behaviourism, London: Cape.

Storey, J. (1989). From personnel management to human resource management. In J. Storey (Ed.), New perspectives on human resource management (pp. 18). London: Routledge.

Sun, L., \& Bunchapattanasakda, C. (2019). Employee engagement: A literature review. International Journal of Human Resource Studies, 9(1), 63-80. https://doi. org/10.5296/ijhrs.v9i1.14167

Tonelli, A.O., De Souza Bermejo, P.H., Aparecida Dos Santos, P., Zuppo, L., \& Zambalde, A.L. (2017). It governance in the public sector: A conceptual model. Information Systems Frontiers, 19, 593-610. https://doi.org/10.1007/s10796-015-9614-x

Vroom, V.H. (1964). Work and motivation. San Francisco, CA: Jossey-Bass.

Yin, R.K. (2009). Case study research methods: Design and methods. Thousand Oaks, CA: Sage.

Zinyama, T., Nhema, A.G., \& Mutandwa, H. (2015). Performance management in Zimbabwe: Review of current issues. Journal of Human Resources Management and Labour Studies, 3(2), 1-27. https://doi.org/10.15640/jhrmls.v3n2a1 